\title{
Pengaruh Penggunaan Miniatur Pada Materi Gaya Terhadap Hasil Belajar Siswa Kelas VIII SMPN 15 Mataram
}

\author{
Intan Kusuma Wardani \\ Universitas Pendidikan Mandalaika \\ intankusumawardani@ikipmataram.ac.id
}

\begin{abstract}
Abstrak
Penelitian ini bertujuan untuk mengetahui pengaruh penggunaan miniatur pada materi gaya terhadap hasil belajar siswa kelas VIII semester 2 SMPN 15 Mataram. Jenis penelitian yang digunakan adalah penelitian eksperimen dengan model desain Randomized Posttest-Only Control Group Design. Populasi dalam penelitian ini adalah seluruh siswa kelas VIII SMPN 15 Mataram. Sampel yang digunakan adalah siswa kelas VIII $_{\mathrm{K}}$ yang berjumlah 39 orang sebagai kelas kontrol dan siswa kelas $\mathrm{VIII}_{\mathrm{A}}$ yang berjumlah 42 orang sebagai kelas eksperimen yang diambil dengan teknik random sampling. Data dalam penelitian ini diambil dengan memberikan tes akhir kepada siswa kelas sampel. Teknik pengumpulan data dengan menggunakan tes objektif yang telah diuji validitas, reliabilitas, daya pembeda, dan taraf kesukarannya. Berdasarkan data hasil tes akhir menunjukkan rata-rata kelas eksperimen sebesar 73,45 dan kelas kontrol sebesar 53,65 tes akhir siswa kelas sampel dianalisis menggunakan uji-t. Hasil analisis data menggunakan uji-t diperoleh $t_{\text {hitung }}$ sebesar 4,107 dan $t_{\text {tabel }}$ 1,99. Didapatkan $t_{\text {hitung }}$ lebih besar dari $t_{\text {tabel }}$ pada taraf kesalahan $5 \%$ dan $\mathrm{dk}$ sebesar 77 maka dapat disimpulkan bahwa terdapat pengaruh yang signifikan dari penggunaan miniatur pada materi gaya terhadap hasil belajar siswa kelas VIII semester 2 SMPN 15 Mataram tahun pelajaran 2011/2012.
\end{abstract}

Kata Kunci : Media Miniatur, Hasil Belajar Siswa

\section{PENDAHULUAN}

Pembelajaran yang kreatif memang bukanlah pilihan yang gampang, di dalamnya memerlukan waktu yang lebih dan perencanaan yang matang untuk melahirkan dan mengembangkan ide baru. Selain itu, diperlukan juga keyakinan yang kuat untuk melakukan improvisasi dalam pembelajaran, keberanian untuk mencoba dan kesanggupan untuk menanggung berbagai resiko yang tidak diharapkan dalam pembelajaran. kendati harus dilakukan melalui usaha yang tidak mudah, pembelajaran untuk kreativitas ini diyakini dapat menjadikan pembelajaran jauh lebih menyenangkan dan memberikan efektivitas yang tinggi.

Permasalahan pokok guru SMP pada umumnya tidak jauh berbeda dari permasalahan guru pada umumnya. Salah satu permasalahan dalam bidang pendidikan adalah sulitnya pemahaman siswa dalam menerima materi yang disampaikan guru pada proses belajar mengajar. Hal ini didukung dari hasil observasi peneliti terhadap siswa dan wawancara dengan guru bidang studi fisika di
SMP Negeri 15 Mataram didapatkan bahwa materi pelajaran fisika oleh sebagian siswa merupakan pelajaran yang dianggap sangat sulit, baik dalam penentuan rumus atau bahkan pemahaman konsep yang terkait dalam pengaplikasian di kehidupan seharihari.

Selain itu pula siswa akan tertarik dengan pelajaran yang sesuai dengan minat mereka dan dianggap mudah. Mereka akan kurang tertarik dengan pelajaran yang tidak ada kaitannya dengan pengalaman, membosankan dan diajar dengan cara yang tidak menyenangkan. Hal ini tentu saja akan berpengaruh terhadap hasil belajar yang dicapai. Dari hasil observasi dan wawancara dengan guru mata pelajaran fisika kelas VIII SMPN 15 Mataram, masalah-masalah yang dihadapi saat proses pembelajaran fisika berlangsung, diantaranya yaitu minat belajar siswa kurang, kurangnya aktivitas/respon siswa dalam menerima pelajaran, dan sebagian siswa menganggap bahwa materi pelajaran fisika merupakan pelajaran yang dianggap sangat sulit, baik dalam penentuan 
rumus atau bahkan pemahaman konsep yang terkait dalam pengaplikasian di kehidupan sehari-hari.

Hal inilah yang menjadi masalah selama ini, sehingga peneliti ingin menerapkan sebuah media pembelajaran berupa miniatur fisika yang dipadukan dengan metode demonstrasi yang lebih memfokuskan pentingnya keaktifan siswa (StudentCentered) dalam hal keingintahuannya untuk memahami konsep fisika disamping itu, tujuan dari pembelajaran pun dapat tercapai.

Tujuan pembelajaran fisika menuntut keterlibatan siswa yang lebih besar dalam proses pembelajaran, oleh karena itu penerapan media miniatur fisika dapat menjadikan kegiatan belajar mengajar lebih menarik dan aktif sehingga pelajaran fisika tidak lagi menjadi materi yang membosankan dan tidak diminati siswa. Berdasarkan uraian di atas terlihat alasan utama dari pemilihan media pembelajaran berupa miniatur fisika dengan menerapkan metode demonstrasi, karena media ini mengajak siswa untuk berpikir kreatif dalam pemahaman konsep fisika di kehidupan sehari-hari. Siswa dapat belajar sambil bermain dan mampu menerapkan konsep fisika konsep yang telah mereka pelajari kemudian dapat memotivasi siswa untuk belajar di rumah sebelumnya, karena pada pelaksanaannya media ini mengajak siswa untuk tidak berkutat pada rumus saja.

Siswa diajak menceritakan dan membahas materi fisika melalui miniatur tersebut dengan terlebih dahulu memerhatikan guru mendemonstrasikan materi gaya menggunakan miniatur. Keinginan siswa untuk mengetahui cerita dari pendemonstrasian yang dilakukan guru membuat siswa termotivasi untuk memerhatikan guru dan bersemangat dalam belajar. Hal ini akan mendorong siswa agar tetap mempertahankan perhatiannya selama proses kegiatan pembelajaran berlangsung.

Belajar

Menurut pengertian secara psikologis, belajar merupakan suatu proses perubahan yaitu perubahan tingkah laku sebagai hasil dari interaksi dengan lingkungannya dalam memenuhi kebutuhan hidup. Perubahan- perubahan tersebut akan nyata dalam seluruh aspek tingkah laku. Perubahan yang terjadi dalam diri seseorang banyak sekali baik sifat maupun jenisnya karena itu sudah tentu tidak setiap perubahan dalam diri seseorang merupakan perubahan dalam arti belajar (Daryanto, 2010).

Menurut Biggs dalam buku Muhibbin (2010) mendefinisikan belajar dalam tiga macamrumusan, yaitu: rumusan kuantitatif; rumusan institusional; rumusan kualitatif. Secara kuantitatif (ditinjau dari sudut jumlah), belajar berarti kegiatan pengisian atau pengembangan kemampuan kognitif dengan fakta sebanyak-banyaknya. Jadi belajar, dalam hal ini dipandang dari sudut berapa banyak materi yang dikuasai siswa. Secara institusional (tinjauan kelembagaan), belajar dipandang sebagai proses validasi (pengabsahan) terhadap penguasaan siswa atas materi-materi yang telah dipelajari. Bukti institusional yang menunjukkan siswa telah belajar dapat diketahui dalam hubungannya dengan proses mengajar. Ukurannya ialah, semakin baik mutu mengajar yang dilakukan guru maka akan semakin baik pula mutu perolehan siswa yang kemudian dinyatakan dalam bentuk skor atau nilai. Adapun pengertian belajar secara kualitatif (tinjauan mutu) ialah proses memperoleh arti-arti dan pemahaman-pemahaman serta cara-cara menafsirkan dunia di sekeliling siswa. Belajar dalam hal ini difokuskan pada tercapainya daya pikir dan tindakan yang berkualitas untuk memecahkan masalah-masalah yang kini dan nanti dihadapi siswa.

Dari kedua definisi tersebut secara umum belajar dapat dipahami sebagai tahapan perubahan secara tingkah laku individu yang relatif menetap sebagai hasil pengalaman dan interaksi dengan lingkungan yang melibatkan proses kognitif, afeksi dan psikomotor.

\section{Pembelajaran Fisika}

Menurut

Hamalik

(2003)

Pembelajaran adalah suatu kombinasi yang tersusun, meliputi unsur-unsur manusiawi, material, fasilitas, perlengkapan, dan prosedur yang saling mempengaruhi untuk mencapai tujuan pembelajaran.

\section{Hasil Belajar Fisika}


Hasil belajar bukan suatu penguasaan hasil latihan melainkan pengubahan kelakuan (Hamalik, 2007). Hasil belajar dalam kelas harus dapat dilaksanakan ke dalam situasi-situasi diluar sekolah. Dengan kata lain, murid dapat mentransfer hasil belajar itu ke dalam situasi-situasi yang sesungguhnya di dalam masyarakat.

Metode mengajar merupakan suatu cara yang dilakukan oleh seorang guru untuk dapat menyajikan bahan pelajaran kepada siswanya dengan baik, metode yang digunakan harus dapat memberikan kemudahan kepada siswa untuk menguasai bahan yang diajarkan berkenaan dengan kemampuan siswa untuk dapat menangkap pengertian dan makna yang disajikan oleh guru.

Berdasarkan uraian di atas dapat disimpulkan bahwa yang dimaksud dengan hasil belajar adalah prestasi yang diperoleh berupa kesan-kesan yang mengakibatkan perubahan dalam diri individu baik berupa sikap, kebiasaan, dan keterampilan sebagai hasil dari aktivitas belajar.

\section{Fungsi dan Peranan Guru Sebagai Pendidik}

Dalam proses belajar-mengajar, guru mempunyai tugas untuk mendorong, membimbing, dan memberi fasilitas belajar bagi siswa untuk mencapai tujuan. Guru mempunyai tanggung jawab untuk melihat segala sesuatu yang terjadi dalam kelas untuk membantu proses perkembangan siswa. Penyarnpaian materi pelajaran hanyalah merupakan salah satu dari berbagai kegiatan dalam belajar sebagai suatu proses yang dinamis dalam segala fase dan proses perkembangan siswa.

Secara lebih terperinci fungsi dan peranan guru berpusat pada:

1. Mendidik dengan titik berat memberikan arah dan motivasi pencapaian tujuan baik jangka pendek maupun jangka panjang.

2. Memberi fasilitas pencapaian tujuan melalui pengalaman belajar yang memadai.
Membantu perkembangan aspekaspek pribadi seperti sikap, nilai-nilai, dan penyesuaian diri. Dalam proses belajarmengajar guru tidak terbatas sebagai penyampai ilmu pengetahuan akan tetapi lebih dari itu, ia bertanggung jawàb akan keseluruhan perkembangan kepribadian siswa. harus mampu menciptakan proses belajar yang sedemikian rupa sehingga dapat merangsang siswa untuk belajar secara aktif dan dinamis dalam memenuhi kebutuhan dan menciptakan tujuan (Slameto, 2010).

\section{Media Pembelajaran Fisika}

Istilah media berasal dari bahasa latin yang merupakan bentuk jamak dari kata medium yang secara harfiah berarti perantara atau pengantar. Jadi, makna umumnya adalah segala sesuatu yang dapat menyalurkan informasi dari sumber informasi kepada penerima informasi (Djamarah, 2006).

Menurut Ibrahim (2010) media pembelajaran dapat diartikan sebagai segala sesuatu yang dapat digunakan untuk menyalurkan pesan atau isi pelajaran, merangsang pikiran, perasaan, perhatian dan kemampuan siswa sehingga dapat mendorong proses belajar mengajar.

\section{METODE PENELITIAN}

Jenis penelitian yang digunakan adalah penelitian eksperimen. Penelitian eksperimen adalah suatu cara untuk mengetahui sebab akibat antara dua faktor yang sengaja ditimbulkan oleh peneliti dengan mengeliminasi atau mengurangi faktor-faktor lain. Jenis penelitian ini selalu dilakukan dengan maksud untuk melihat akibat dari suatu perlakuan (Arikunto, 2010). Salah satu ciri penelitian eksperimen adalah menggunakan kelompok kontrol sebagai garis dasar untuk dibandingkan dengan kelompok yang dikenai eksperimen. Pada penelitian ini akan mengeksperimenkan penggunaan miniatur pada materi gaya.

\section{a. Pembahasan}

Berdasarkan hasil analisis data tes akhir yang telah dilakukan, diketahui bahwa hasil belajar siswa kelas eksperimen lebih baik dari pada kelas Kontrol. Nilai tertinggi kelas eksperimen adalah 90 sedangkan nilai 
tertinggi kelas kontrol adalah 80. Nilai ratarata kelas eksperimen adalah 73,45 sedangkan nilai rata-rata kelas kontrol adalah 53,65. Setelah dilakukan uji statistik dengan uji t pada taraf nyata 0,05 diperoleh $t_{\text {hitung }}=4,107$ dan $t_{\text {tabel }}=1,99$ berarti $t_{\text {hitung }}$ lebih besar daripada $t_{\text {tabel. }}$. Dengan demikian disimpulkan bahwa hipotesis kerja diterima. Hipotesis penelitian berbunyi "Penggunaan media miniatur berpengaruh terhadap hasil belajar siswa kelas VIII SMP Negeri 15 Mataram Tahun Pelajaran 2011/2012.

Hasil belajar siswa kelas eksperimen pada aspek kognitif lebih baik dibandingkan kelas kontrol disebabkan karena pada kelas eksperimen, siswa menggunakan media miniatur sebagai perantara untuk lebih memahami tujuan dari pembelajaran tersebut. dalam hal ini peneliti mempunyai alasan mengapa penggunaan miniatur ini dilakukan di kelas VIII, hal itu di karenakan masa transisi secara psikologis jiwa anak-anak yang masih terbawa dari SD hingga SMP masih terasa. Sehingga peneliti menggunakan media miniatur ini untuk mampu mendalami faktor transisi psikologi siswa dari anak-anak menuju ke remaja. Penggunaan media miniatur tidak lepas pula dengan metode demonstrasi yang diterapkan, karena dalam hal ini guru yang memberikan contoh cara penggunaan miniatur ini pada setiap pertemuan. Kemudian, siswa secara berkelompok mampu menjelaskan kepada teman-temannya mengenai materi yang diajarkan, miniatur disesuaikan dengan apa yang dibahas oleh guru. Sehingga terjadi diskusi antar siswa dengan siswa, guru dengan siswa, siswa dengan guru dan pengasahan kemampuan untuk mengaplikasikan materi gaya dalam kehidupan sehari-hari melalui media miniatur dan mendiskusikannya dengan teman mereka yang memiliki pengetahuan, pengalaman yang bermacam-macam.

Pada penggunaan media miniatur
siswa dapat membandingkan antara
pengetahuan yang mereka miliki sebelum
mengikuti pembelajaran dengan saat setelah
siswa mengikuti pembelajaran sehingga siswa
dapat mengetahui sendiri perkembangan
kemampuannya dan meningkatkan

kemampuannya secara optimal. karena tujuan dibuatnya miniatur ini untuk mengasah pengalaman pribadi yang pernah mereka rasakan sesuai dengan materi yang diajarkan. materi tidak jauh berbeda penerapannya dalam kehidupan sehari-hari dengan teori yang ada di buku.

Berdasarkan penilaian yang dilakukan pada aspek kognitif terhadap kedua kelas sampel dapat diketahui hasil belajar fisika yang diperoleh masing-masing kelas sampel menunjukkan adanya pengaruh perbedaan perlakuan yang diterima kedua kelas. Jadi, penggunaan media miniatur pada materi gaya berpengaruh terhadap hasil belajar fisika

\section{KESIMPULAN}

Berdasarkan hasil penelitian dan pembahasan, maka dapat ditarik simpulan bahwa. "penggunaan media miniatur pada materi gaya berpengaruh terhadap hasil belajar siswa kelas VIII SMP Negeri 15 Mataram

\section{SARAN}

Berdasarkan hasil penelitian yang diperoleh, maka ada beberapa hal yang dapat disarankan, yaitu:

a. Bagi siswa, melatih siswa agar dapat lebih aktif dan mandiri dalam kegiatan pembelajaran yaitu dalam penggunaan media.

b. Bagi guru, media miniatur dengan kolaborasi metode demonstrasi atau bahkan dapat digunakan metode yang lain dapat dijadikan alternatif dalam upaya meningkatkan hasil belajar siswa.

c. Bagi peneliti, memperoleh pengalaman langsung karena penelitian ini melibatkan proses belajar mengajar di sekolah dan memperoleh pengetahuan tentang pengaruh dari penggunaan media miniatur dengan menerapkan metode demonstrasi.

d. Bagi sekolah, merupakan informasi tentang perkembangan siswa mengenai hasil belajar siswa menggunakan media miniatur ini.

\section{DAFTAR PUSTAKA}

Ahmadi. 2005. Strategi Belajar Mengajar. Bandung: Pustaka Setia

Ali, Lukman. 1991. Kamus Besar Bahasa Indonesia. Jakarta: Balai Pustaka 
Arifin, Z. 2011. Evaluasi Pembelajaran. Bandung: PT Remaja Rosdakarya

Arikunto, Suharsimi. 2010. Dasar-dasar Evaluasi Pendidikan. Jakarta: Bumi Aksara.

Arikunto, Suharsimi. 2010. Prosedur Penelitian Suatu Pendekatan Praktik. Jakarta: Rineka Cipta

Arsyad, Azhar. 2004. Media Pembelajaran. Jakarta: Raja Grafindo

Asril, Zainal. 2010. Microteaching. Jakarta: Rajawali Pers.

Daryanto. 2011. Media Pembelajaran. Bandung: Satu Nusa

Dimyati. 2006. Belajar Dan Pembelajaran. Jakarta: Rineka Citra.

Djamarah, S. B. 2002. Psikologi Belajar. Jakarta: Rineka Cipta

Hamalik, O. 2003. Kurikulum dan Pembelajaran. Jakarta: Bumi Aksara

Hamalik, Oemar. 2007. Proses Belajar Mengajar. Jakarta : Bumi Aksara

Ibrahim, dkk. 2010. Perencanaan Pengajaran. Jakarta: Rineka Cipta

Juliansyah, Tiana. 2010. Kiat-kiat Terbaik untuk Guru. Bandung: Setia Purna

Riduwan. 2010. Belajar Mudah Penelitian. Bandung: Alfabeta

Roestiyah N.K. 1998. Srategi Belajar Mengajar. Jakarta: : Rineka Citra.

Sagala, S. 2008. Konsep dan Makna Pembelajaran. Bandung: Alfabeta

Sanjaya, W. 2010. Strategi Pembelajaran Berorientasi Standar Proses Pendidikan. Jakarta: Kencana

Sardiman, 2011. Interaksi dan Motivasi Belajar Mengajar. Jakarta: Rajawali Pers

Slameto. 2010. Belajar dan Faktor-Faktor yang Mempengaruhinya. Jakarta: Rineka Cipta

Sudjana. 2005. Metoda Statistika. Bandung: Tarsito

Sugiyono, 2011. Metode Penelitian Pendidikan Pendekatan Kuantitatif, Kualitatif, R\&D. Bandung: Alfabeta

Sukmadinata, Nana. 2010. Metode Penelitian Pendidikan. Bandung: Rosda

Suryabrata, Sumadi. 2009. Metode Penelitian. Jakarta: Rajawali Pers
Syah, Muhibbin. 2010. Psikologi Belajar. Jakarta: Logos

Tim Penyusun. 2011. Pedoman Pembimbingan dan Penulisan Karya Ilmiah. Mataram: IKIP Mataram. 